\title{
A controlled-release fertilizer improved soil fertility but not olive tree performance
}

\author{
Ermelinda Silva (1) - Margarida Arrobas (1) Alexandre Gonçalves (1) •

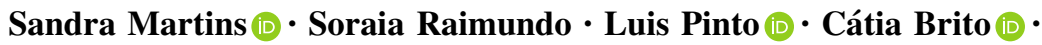 \\ José Moutinho-Pereira $[$ Carlos M. Correia $[$ C $\cdot$ M.Ângelo Rodrigues
}

Received: 2 November 2020/ Accepted: 22 March 2021/Published online: 9 April 2021

(C) The Author(s), under exclusive licence to Springer Nature B.V. 2021

\begin{abstract}
The use of a controlled-release fertilizer (CRF) was studied in a traditional rainfed olive grove in a Mediterranean climate where precipitation is very irregular, particularly in the spring. The objective of the study was to assess whether a CRF can improve the olive tree's performance compared to a conventional nitrogen $(\mathrm{N})$ fertilizer $(\mathrm{CF})$, by supplying $\mathrm{N}$ gradually and reducing the risk of potential $\mathrm{N}$ loss from leaching. The fertilized treatments showed better plant $\mathrm{N}$ nutritional status, which resulted in enhanced net photosynthesis and higher leaf concentrations of total soluble sugars, chlorophylls and soluble proteins
\end{abstract}

Supplementary information The online version contains supplementary material available at https://doi.org/10.1007/ s10705-021-10134-9.

E. Silva · A. Gonçalves - S. Martins ·

L. Pinto · C. Brito · J. Moutinho-Pereira - C. M. Correia Centre for the Research and Technology of AgroEnvironmental and Biological Sciences (CITAB), Centre for the Research and Technology, University of Trás-osMontes e Alto Douro, Vila Real, Portugal

M. Arrobas · A. Gonçalves · S. Raimundo ·

L. Pinto $\cdot$ M.Ângelo Rodrigues $(\bowtie)$

Centro de Investigação de Montanha (CIMO), Instituto

Politécnico de Bragança, Campus de Sta Apolónia,

5300-253 Bragança, Portugal

e-mail: angelor@ipb.pt

A. Gonçalves · L. Pinto

Collaborative Laboratory Mountains of Research,

Brigantia Ecopark, 5300-358 Bragança, Portugal which, in turn, increased olive yield by $43 \%$ in comparison to the unfertilized control. However, in general, no significant differences were found between fertilized treatments in the performance parameters of the trees evaluated, including olive yield. Somewhat unexpectedly, CRF consistently increased the soil organic carbon (C) (29\%), kjeldahl-N (75\%) and easily extractable glomalin-related soil proteins (EEGRSP) (60\%) and total GRSP (T-GRSP) (122\%) compared to the $\mathrm{CF}$. The result was ascribed to a stimulus on the development of herbaceous vegetation and eventually on the activity of the roots of the trees due to the higher soil inorganic- $\mathrm{N}$ availability in the autumn. Thus, some soil inorganic- $\mathrm{N}$ in the autumn seems to comprise a low risk of leaching, since weeds act as a catch crop and convert this inorganic $\mathrm{N}$ into an organic substrate, with potential benefits in the longterm for the agro-system.

Keywords Olea europaea - Nitrogen fertilization . Net photosynthesis - Relative water content $\cdot$ Soil organic carbon $\cdot$ Glomalin-related soil proteins

\section{Introduction}

In recent decades, olive growing has undergone great changes in some producing regions mainly by increasing cropping intensification. The irrigated hectarage 
increased, and in some new plantations high tree densities were used, sometimes higher than 2000 trees per hectare, as occurs in hedgerow olive orchards (Navarro et al. 2017). However, in many other important olive-growing regions along the Mediterranean basin, irrigation is not yet possible, either due to lack of water, irrigation infrastructures or the small size of the plots (Rodrigues and Arrobas 2020). Hence, traditional rainfed olive groves still retains huge economic importance for local populations. In some municipalities of the NE of Portugal, for instance, olive is currently the only cash crop, so the failure of this crop will further aggravate the depopulation of these territories. Olive is currently grown by some professional farmers, but also by several other small landowners, employed in other sectors of the economy, which manage their farms during the weekend, days-off and holidays. This type of agriculture is also being encouraged politically since it can provide a wide range of ecosystem services, other than food production, such as wildfires reduction by creating a mosaic of discontinuity of olive orchards between scrub and forest areas (EIDT 2015).

Apart from the fragile economic situation of these farms, currently caused by the low productivity of rainfed olive groves and the low price of olive oil, the future is doubtful also due to the sector's vulnerability to climate change which tends to aggravate the general growing conditions. Climate change is currently a great challenge for agricultural activities. In Portugal, in the regions where the olive tree is usually grown, which benefit from a Mediterranean type climate, along with an increase in air temperature and a reduction in annual precipitation, extreme weather events such as heat waves, droughts and extreme rainfall events are expected to occur with increased frequency (Fraga et al. 2017; Quinteiro et al. 2019). To deal with this adverse scenario the cropping techniques should be constantly adjusted for the mitigation of the effects of climate change (Correia and Rodrigues 2020).

Fertilization efficiency is closely related to regular soil water availability. The mobility of nutrients in the soil by mass flow and diffusion, and nutrient uptake by roots rely on good soil water conditions (Marschner and Rengel 2012). On the other hand, the efficient use of mobile nutrients in the soil, such as $\mathrm{N}$, could be severely reduced by prolonged rainfall events, since $\mathrm{N}$ is very sensitive to be lost from the soil by leaching
(Mulla and Strock 2008) or denitrification (Coyne 2008). In traditional rainfed managed orchards, fertilizers are commonly applied to the soil usually in late winter or early spring to reduce the risk of nitrate leaching and denitrification (Fernández-Escobar 2017; Arrobas et al. 2019). Application of fertilizers cannot be delayed as this can reduce nutrient uptake efficiency due to the increased risk of low water availability. In the Mediterranean basin, precipitation shows high inter-annual variability, particularly in spring and autumn, the transition seasons, a situation that will be worsen in the context of climate change (Carvalho et al. 2014; Campos et al. 2017), making it difficult to make a good decision about when to apply mobile nutrients to the soil.

Theoretically, this agro-ecological context seems to claim for the use of fertilizers that can delay initial nutrient availability, or extended time of continued availability as a mean of reduction nutrient loss from the soil, lowering its vulnerability to the unpredictability of rainfall events. A variety of technologies have been developed to provide fertilizers with such properties. Some of the most prominent are commercially classified as controlled-release fertilisers (CRF), which are products containing a conventional fertiliser but nutrient release in the soil is regulated by sulphur and/or polymer coatings (Trenkel 2010; Wei et al. 2020). Fertilizers with such mechanisms of controlledrelease have been developed for hard nutrient management contexts, such as flooded rice (Ke et al. 2017), sandy soils (Guertal 2000; Chilundo et al. 2016), nursery-grown and potted plants or vegetated roofs (Emilsson et al. 2007; Adams et al. 2017; Chu et al. 2019), to increase nutrient use efficiency or to reduce the risk of young plants' damage by salinity.

The application of $\mathrm{N}$ fertilizers to the soil in rainfed olive groves is a difficult $\mathrm{N}$ management context where the use of CRF has not yet been sufficiently evaluated. It is necessary to consider that although these fertilizers have been developed with the aim to match nutrient release to crop demand, in several studies no advantages were found in their use in relation to conventional fertilizers (Guertal 2000; Arrobas et al. 2011; Chilundo et al. 2016). Therefore, their generalization in each agricultural context must be preceded by technical feasibility studies, because they tend to be more expensive than the fertilizers of high nutrient solubility. 
Thus, the working hypothesis of this study is whether a CRF can improve olive tree's nutritional status and crop productive performance compared to a conventional fertilizer where nutrients are readily available for uptake, in an environment where rainfall events are unpredictable during the spring-summer period. The CRF is applied at the same and at half the rate of that of a conventional fertilizer, based on a theoretical assumption that by increasing $\mathrm{N}$ use efficiency, the CRF can be used in a smaller rate to obtain a similar performance on tree growth and yield.

\section{Materials and methods}

Characterisation of the experimental site

The field experiment was carried out during three consecutive growing seasons (2016-2018) in Macedo de Cavaleiros (41.446567, -6.822091), Northeast of Portugal. The region benefits from a Mediterranean type climate. Average annual precipitation and temperature are $550 \mathrm{~mm}$ and $13.5^{\circ} \mathrm{C}$. During the experimental period, average minimum and maximum temperatures varied from 6.2 to $23.8^{\circ} \mathrm{C}, 4.0$ to $22.7^{\circ} \mathrm{C}$ and 4.5 to $23.4^{\circ} \mathrm{C}$ and annual precipitation reached $786.1,505.7$ and $706.3 \mathrm{~mm}$, respectively in 2016, 2017 and 2018 (Figure S1). The soil is a Leptosol derived from schist, which is the most representative soil type in the region, loamy-sand textured $(77.7 \%$ sand, $18.9 \%$ silt, and $3.4 \%$ clay). From soil samples $(0-0.2 \mathrm{~m})$ taken at the beginning of the experiment, the soil showed to be acid $(\mathrm{pH}=5.9)$ and low in organic $\mathrm{C}\left(4.6 \mathrm{~g} \mathrm{~kg}^{-1}\right)$ and total $\mathrm{N}$ $\left(0.4 \mathrm{~g} \mathrm{~kg}^{-1}\right)$. Extractable phosphorus (P), potassium (K) and boron (B) were, respectively, low (48.3 mg $\left.\mathrm{P}_{2} \mathrm{O}_{5} \mathrm{~kg}^{-1}\right)$, high $\left(81.5 \mathrm{mg} \mathrm{K}_{2} \mathrm{O} \mathrm{kg}^{-1}\right)$ and very high (1.89 $\mathrm{mg} \mathrm{B} \mathrm{kg}^{-1}$ ). Exchangeable calcium (Ca), magnesium $(\mathrm{Mg}), \mathrm{K}$, sodium $(\mathrm{Na})$ and acidity are respectively $7.41,1.01,0.11,0.31$ and $0.25 \mathrm{cmol}_{\mathrm{c}} \mathrm{kg}^{-1}$. The methods of soil analyses used to characterize the experimental plot and those used to assess the effect of the fertilizer treatments at the end of the trial will be provided in the "Laboratory analysis" Section.

The orchard was planted in March 2000 (16 yearsold at the beginning of the study). The trees of cv. Cobrançosa were planted spaced at $7 \mathrm{~m} \times 7 \mathrm{~m}$ $\left(\sim 204\right.$ trees $\left.\mathrm{ha}^{-1}\right)$. Since planting, the trees were subject to a light annual pruning regime, being quite homogeneous in relation to the crown volume at the trial start. The farmer used to manage the weeds through the application of glyphosate (N-(phosphonomethyl) glycine, $360 \mathrm{~g} \mathrm{~L}^{-1}$ of active ingredient), a post-emergence herbicide, applied at a rate of $3 \mathrm{~L} \mathrm{ha}^{-1}$ in early April. No other phytosanitary products were applied during the year. The fertilization performed by the farmer in the last growing season (March 2015) consisted of the application of $30 \mathrm{~kg} \mathrm{ha}^{-1}$ of N, $\mathrm{P}_{2} \mathrm{O}_{5}$ and $\mathrm{K}_{2} \mathrm{O}$ as a compound NPK $(15: 15: 15)$ fertilizer plus $1 \mathrm{~kg} \mathrm{ha}^{-1}$ of $\mathrm{B}$ as borax.

\section{Fertilizer treatments}

Four fertilizer treatments were established, namely: 1) controlled-release fertilizer applied at a rate of $40 \mathrm{~kg} \mathrm{~N} \mathrm{ha}^{-1}$ (CRF.40 N); 2) CRF applied at $20 \mathrm{~kg} \mathrm{~N} \mathrm{ha}^{-1}$ (CRF.20 N); 3) conventional fertilizer (CF) applied at a rate of $40 \mathrm{~kg} \mathrm{~N} \mathrm{ha}^{-1}(\mathrm{CF} .40 \mathrm{~N})$; and 4) control, without $N$. These fertilizer treatments were chosen taking into account the $\mathrm{N}$ rates commonly used in the region by this and other farmers and the age of the trees. The highest $\mathrm{N}$ rates were $40 \mathrm{~kg} \mathrm{ha}^{-1}$ resulting in the treatments CRF.40 N and CF.40 N. The CRF was also used in half the rate to create a second level of comparison with $\mathrm{CF}$ in case it proves to be more efficient in using $\mathrm{N}$. The experiment was arranged as a completely randomized design with three replicates. The experimental units, or replicates, were composed of groups of three homogeneous trees, occupying an area of $147 \mathrm{~m}^{2}$.

The CRF (Boskgrow mixcote 21:7:14®, AtlanlusiEurope, Lda.) is a compound NPK $\left(21 \% \mathrm{~N}, 7 \% \mathrm{P}_{2} \mathrm{O}_{5}\right.$, $14 \% \mathrm{~K}_{2} \mathrm{O}$ ) fertilizer. $\mathrm{N}$ in the $\mathrm{CRF}$ is in the forms of nitrate (1.6\%), ammonium (3.8\%) and urea (15.6\%). Part of N (26.3\% of total) is polyurethane coated urea and other part (47.5\% of total) is ammonium sulphate coated urea, a $\mathrm{N}$ protection mechanism lasting three months in average. The conventional fertilizers used were ammonium nitrate $(20.5 \% \mathrm{~N}, 50 \%$ nitrate-N and $50 \%$ ammonium-N), simple superphosphate (18\% $\left.\mathrm{P}_{2} \mathrm{O}_{5}\right)$, and potassium chloride $\left(60 \% \mathrm{~K}_{2} \mathrm{O}\right)$. All the treatments received the same rates of $\mathrm{P}$ and $\mathrm{K}$ as the CRF.40 N treatment. B is one the most common nutritional disorder in the region (Arrobas et al. 2019). Regional labs recommend annual rates of $2 \mathrm{~kg} \mathrm{~B} \mathrm{ha}^{-1}$ to mature orchards. To avoid any negative influence in the response to fertilizer treatments, and considering the youth of the trees, $1 \mathrm{~kg} \mathrm{~B} \mathrm{ha}^{-1}$ was also annually 
applied to all the trees included in the experiment, just as the farmer had been doing in recent years. All the fertilizers were homogeneously spread beneath the tree crown, those considered in the experimental design in the respective plot and B applied in all plots. The fertilizers were applied in the last week of March as is usual in the region. Soil management and pruning during the experimental period were done by the farmer as above mentioned.

Field analyses and sample collection

All physiological and biochemical measurements at leaf level were taken in healthy and full expanded mature leaves. The leaf gas exchange, leaf sclerophylly and relative water content measurements were taken during the 3 years of the experiment, at different stages of the production cycle, starting 3 months after installation and ending about 3 months before the end of the experiment, whereas leaf samples for biochemical analysis were taken at the end of August, usually the peak of drought stress (Brito et al. 2019). For leaf biochemical analysis, the harvested leaves were immediately frozen in liquid $\mathrm{N}$ and stored at $-80^{\circ} \mathrm{C}$ until be analyzed.

Leaf gas exchange measurements were performed on cloudless days (photosynthetic photon flux density above $1500 \mu \mathrm{mol} \mathrm{m} \mathrm{m}^{-2} \mathrm{~s}^{-1}$ ) using a portable IRGA (LCpro + , ADC, Hoddesdon, UK), operating in the open mode. Net photosynthetic rate $\left(\mathrm{A}, \mu \mathrm{mol} \mathrm{CO}_{2}\right.$ $\left.\mathrm{m}^{-2} \mathrm{~s}^{-1}\right)$, stomatal conductance $\left(\mathrm{g}_{\mathrm{s}}\right.$, mmol $\mathrm{H}_{2} \mathrm{O}$ $\mathrm{m}^{-2} \mathrm{~s}^{-1}$ ) and the ratio of intercellular to atmospheric $\mathrm{CO}_{2}$ concentration $\left(\mathrm{C}_{\mathrm{i}} / \mathrm{C}_{\mathrm{a}}\right)$ were estimated using the equations developed by von Caemmerer and Farquhar (1981). Intrinsic water use efficiency was calculated as the ratio of $\mathrm{A} / \mathrm{g}_{\mathrm{s}}\left(\mu \mathrm{mol} \mathrm{mol}{ }^{-1}\right)$.

Leaf samples were taken twice a year in July and December for monitoring the nutritional status of the trees. The sampling method followed the standard for this species (Fernández-Escobar 2017). Young fully expanded leaves were taken from the middle part of the current season shoots around the tree canopy.

Annual pruning wood from each individual tree was weighed fresh. Subsamples, representatives of the mass of stems and leaves, were carried out to the laboratory and oven-dried at $70{ }^{\circ} \mathrm{C}$ until constant weight to express the results as dry matter and to analyse the tissues for elemental composition.
After the last fruit harvest the canopy volume was estimated by measuring the height of the canopy (from basal branches to the top) and the radius of the canopy in the four main quadrants (North, South, East, and West), after it has been observed that the canopies subjected to this pruning regime has a permanent cylindrical shape. Thus, the canopy volume (CV) was estimated using the universal equation to estimate the volume of a cylinder, $\mathrm{CV}=\pi \mathrm{r}^{2} \mathrm{~h}$, where $\mathrm{r}$ and $\mathrm{h}$ are the average radius and height of the canopy.

Fruit harvest was performed in late autumn using a portable branch shaker machine. Panels arranged on the floor allowed the recovery of the fruits. The production of each experimental unit (groups of three trees) was weighed separately.

Soils samples were taken at the trial start (March, 2016) and following the last fruit harvest (December, 2018). The first sampling was done for an initial characterisation of the experimental conditions. Three composite samples (10 individual cores) were taken from all treatments, one per experimental unit, at 0-0.2 m depth and beneath the tree crown. After the last fruit harvest, composite soil samples were taken per experimental unit to assess the effect of the fertilizer treatments in soil properties. Samples were taken beneath the tree crown and separated in two different soil layers (0-0.1 $\mathrm{m}$ and $0.1-0.2 \mathrm{~m}$ ), usually reaching the bed rock of this soil.

\section{Laboratory analysis}

Leaf samples and pruning wood (leaves and stems) were oven-dried at $70{ }^{\circ} \mathrm{C}$ and ground. They were analysed for macro (N, P, K, Ca and $\mathrm{Mg}$ ) and micronutrients $[\mathrm{B}$, iron $(\mathrm{Fe})$, zinc $(\mathrm{Zn})$, cooper $(\mathrm{Cu})$ and manganese $(\mathrm{Mn})]$. N was determined by Kjeldahl (FOSS Kjeltec $^{\mathrm{TM}}$ 8400), B and $\mathrm{P}$ by colorimetry (GENESYS 6 thermospectronic), $\mathrm{K}$ by flame emission spectrometry (Perkin Elmer Pinaacle $900 \mathrm{~T}$ ) and Ca, $\mathrm{Mg}, \mathrm{Cu}, \mathrm{Fe}, \mathrm{Zn}$ and $\mathrm{Mn}$ by atomic absorption spectrophotometry (Perkin Elmer Pinaacle 900 T).

In the field, detached leaves were immediately placed into air-tight containers and in the laboratory the following parameters were examined: fresh mass (FM); mass at full turgor (TM), measured after immersion of leaf petioles in demineralized water for $48 \mathrm{~h}$ in the dark at $4{ }^{\circ} \mathrm{C}$; leaf area (LA), measured using the WinDias image analysis system (Delta-T Devices Ltd., Cambridge, UK); and dry mass (DM), 
measured after drying at $70{ }^{\circ} \mathrm{C}$ to a constant weight. The relative water content was calculated, RWC $(\%)=(\mathrm{FM}-\mathrm{DM}) /(\mathrm{TM}-\mathrm{DM}) \times 100$, to characterize leaf water status, and the sclerophylly index, density of foliar tissue $=\mathrm{DM} / \mathrm{FM}$.

Photosynthetic pigments were extracted with acetone/water (80/20, v/v). Total chlorophylls [Chl(a + b)] were determined according to Arnon (1949) and Sesták et al. (1971) and total carotenoids according to Lichtenthaler (2007). Soluble sugars (SS) were extracted according to Irigoyen et al. (1992), by heating the samples in ethanol/water $(80 / 20, \mathrm{v} / \mathrm{v})$ during $1 \mathrm{~h}$, at $80^{\circ} \mathrm{C}$. Then, SS concentration was determined by the anthrone method (Correia et al. 2005), using glucose as a standard. Total soluble proteins were quantified using the method of Bradford (1976), using bovine serum albumin as a standard.

After drying $\left(40^{\circ} \mathrm{C}\right)$ and sieving $(2 \mathrm{~mm}$ mesh), the soil samples were submitted to analytical determinations: (1) $\mathrm{pH}\left(\mathrm{H}_{2} \mathrm{O}, \mathrm{KCl}\right)$; (2) easily oxidizable $\mathrm{C}$ (Walkley-Black method); (3) Kjeldahl N (sulphuric digestion and $\mathrm{NH}_{4}{ }^{+}$titration by boric acid); (4) cation exchange capacity (ammonium acetate, $\mathrm{pH} 7.0$ ); (5) extractable $\mathrm{P}$ and $\mathrm{K}$ (ammonium lactate); (6) extractable B (hot water and azomethine-H); (7) soil inorganic $\mathrm{N}$, from extractions of ammonium and nitrate by $2 \mathrm{M} \mathrm{KCl}$; (8) easily extractable glomalinrelated soil proteins (EE-GRSP) and total GRSP (TGRSP). In the initial samples there were also determined (9) clay, silt and sand fractions by the Robinson pipette method. Methods 1-6, and 9 are fully described by Houba et al. (1997), method 7 by Baird et al. (2017) and method 8 by Wright and Updahyaya (1998).

\section{Data analysis}

Data was firstly tested for normality and homogeneity of variances using the Shapiro-Wilk test and Bartlett's test, respectively. The comparison of the effect of the fertilizer treatments was provided by one-way ANOVA, since the experiment was arranged as a completely randomised design with a single variation factor. Regarding soil data, the depth was integrated into ANOVA as blocks. When significant differences were found $(\alpha<0.05)$, the means were separated by the multiple range Tukey HSD test $(\alpha=0.05)$.

\section{Results}

Olive yield and canopy growth

Olive yields of 2017 and 2018 varied significantly $(P<0.05)$ among fertilizer treatments as well as the total of three years (Fig. 1). Accumulated olive yields varied from 44.5 to $63.9 \mathrm{~kg}^{-1} \mathrm{ee}^{-1}$ in the control and CF.40 N treatments, respectively. The treatments CF.40 N and CRF.40 N gave significantly higher olive yields than the control. The average olive yield of CRF.20 N was higher than that of control and lower than those of CRF.40 N and CF.40 N, but the values were not significantly different from any of them.

Pruning wood did not vary significantly between fertilizer treatments for each individual year or for accumulated prunings (Fig. 2). Total pruning wood varied from 12.3 to $17.0 \mathrm{~kg}$ tree ${ }^{-1}$, respectively in the control and CRF.40 N treatments. However, the control treatment showed the lower average values. Canopy volume varied significantly between treatments, the control presenting a lower value $\left(19.4 \mathrm{~m}^{3}\right)$ than CRF.40 N $\left(23.9 \mathrm{~m}^{3}\right)$ and CF.40 N (24.4 $\left.\mathrm{m}^{3}\right)$ treatments. CRF. $20 \mathrm{~N}$ average value was midway between that of control and those of the treatments that received $40 \mathrm{~kg} \mathrm{~N}^{-1}$.

Tree nutritional status

Leaf $\mathrm{N}$ concentration varied significantly among fertilizer treatments in five of the six samplings (Fig. 3). Control usually displayed lower values than the other treatments. In general terms, leaf $\mathrm{N}$ concentration decreased over the experimental period in all the treatments but particularly in the control. In the last sampling dates, all the values were below $15 \mathrm{~g} \mathrm{~kg}^{-1}$, the lower limit of the sufficiency range. Leaf $\mathrm{P}$ levels hardly varied among fertilized treatments, but they also decreased during the experimental period from values close to $1.4 \mathrm{~g} \mathrm{~kg}^{-1}$ to values close to or below $1.0 \mathrm{~g} \mathrm{~kg}^{-1}$, the lower limit of the sufficiency range. Leaf $\mathrm{K}$ concentration did not show coherence between fertilizer treatments. Leaf $\mathrm{K}$ values varied greatly within, below and above the sufficiency range (9-12 $\mathrm{g} \mathrm{kg}^{-1}$ ), which is a characteristic of the nutrient. Leaf B levels also showed great variation between sampling dates, but not between fertilizer treatments. Average values, however, varied within the limits of the sufficiency range $\left(20-75 \mathrm{mg} \mathrm{kg}^{-1}\right)$. Leaf $\mathrm{Ca}, \mathrm{Mg}$, 


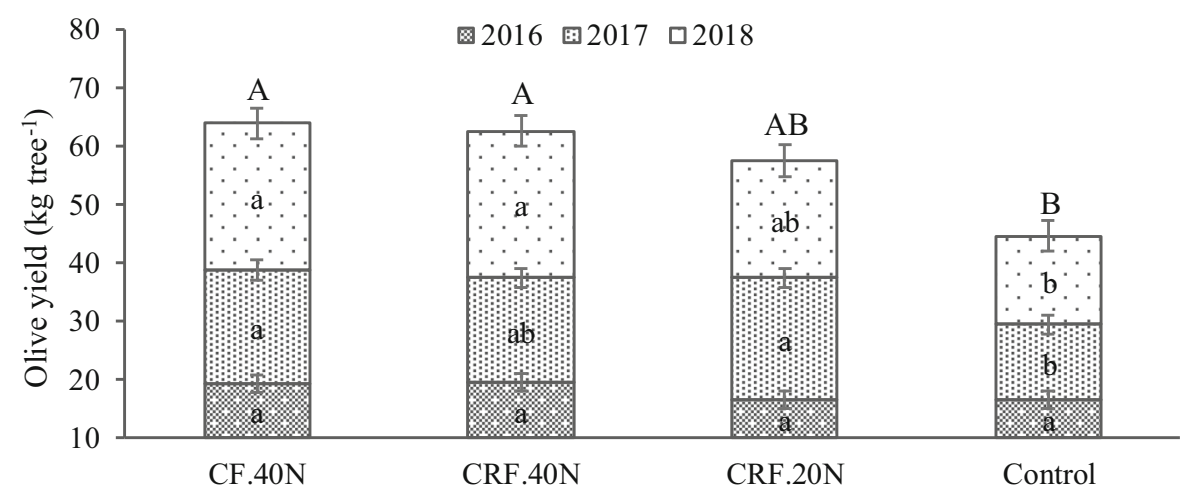

Fig. 1 Annual and cumulative olive yields after the application of a conventional fertilizer (CF) and a controlled-release fertilizer (CRF), applied at the rates of 0 (control), $20(20 \mathrm{~N})$ and $40(40 \mathrm{~N}) \mathrm{kg} \mathrm{N} \mathrm{ha}^{-1}$. Within each year (lowercase letters) and total (uppercase letters), means associated to the same letters are not significantly different by Tukey HSD multiple range test $(\alpha=0.05)$. Vertical bars are standard errors

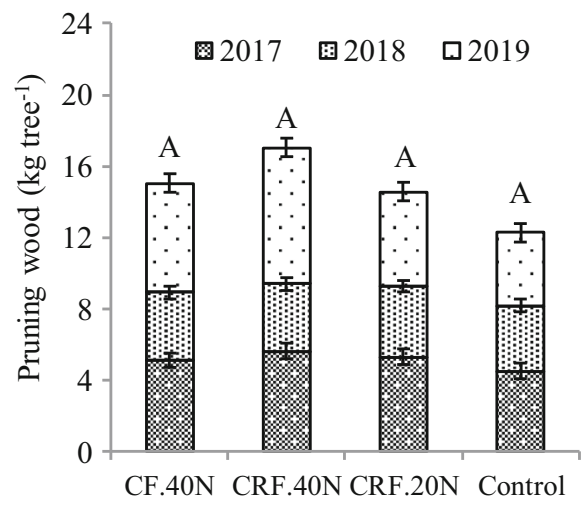

Fig. 2 Pruning wood (left) and canopy volume (right) after the application of a conventional fertilizer (CF) and a controlledrelease fertilizer (CRF), applied at the rates of 0 (control), 20

$\mathrm{Fe}, \mathrm{Cu}, \mathrm{Zn}$ and $\mathrm{Mn}$ levels did not show consistency to help in the interpretation of the effect of treatments (data not shown).

Leaf water relations, sclerophylly and gas exchange

Despite some significant differences, a clear influence of treatments on RWC values was not found (Fig. 4). Meanwhile, in general, unfertilized plants presented higher leaf density, more clearly in the last two sampling dates (2018).

The effect of the fertilizer treatments on leaf gas exchange variables were presented in Fig. 5. After the first year without significant differences among treatments, some dates showed a lower performance of

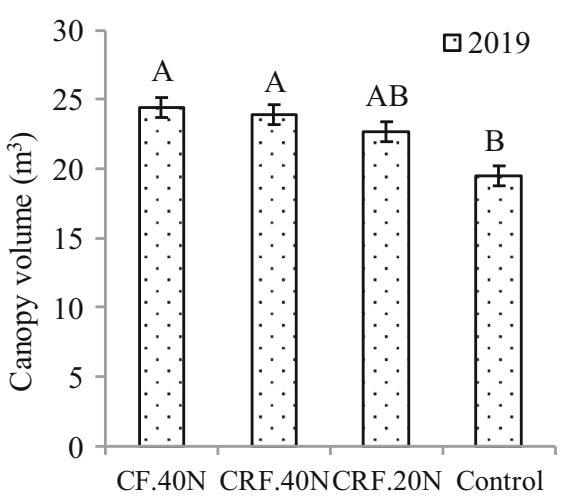

$(20 \mathrm{~N})$ and $40(40 \mathrm{~N}) \mathrm{kg} \mathrm{N} \mathrm{ha}^{-1}$. Uppercase letters above the columns are the result of analysis of variance and Tukey HSD multiple range test $(\alpha=0.05)$. Vertical bars are standard errors

control plants with inferior net photosynthesis, due to stomatal limitations and especially due to mesophyll limitations, as is deduced by the lower $\mathrm{A} / \mathrm{g}_{\mathrm{s}}$ and superior $\mathrm{C}_{\mathrm{i}} / \mathrm{C}_{\mathrm{a}}$ ratio. On the other hand, in general, there was no significant effect of the type of fertilizer and the respective rate on those variables, despite some advantage of CRF, particularly at the rate of $40 \mathrm{~kg} \mathrm{~N} \mathrm{ha}^{-1}$ that enhanced intrinsic water use efficiency in some leaf gas exchange assessments.

Soluble sugars and oxidative stress markers

Total soluble sugars as well as the oxidative stress markers, total chlorophylls and total soluble proteins, were significantly different between treatments, the control plants exhibiting the lowest concentrations 
Fig. 3 Leaf N, P, K and B concentrations from January (J) 2016 to December (D) 2018 after the application of a conventional fertilizer (CF) and a controlled-release fertilizer (CRF), applied at the rates of 0 (Control), 20 $(20 \mathrm{~N})$ and $40(40 \mathrm{~N}) \mathrm{kg} \mathrm{N}$ $\mathrm{ha}^{-1}$. Horizontal dashed lines are the lower and higher limits of the sufficiency ranges; ns (not significant $), *(\mathrm{P}<0.05)$, $* *(\mathrm{P}<0.01)$ and $* * *(\mathrm{P}<0.001)$ are the results of analysis of variance
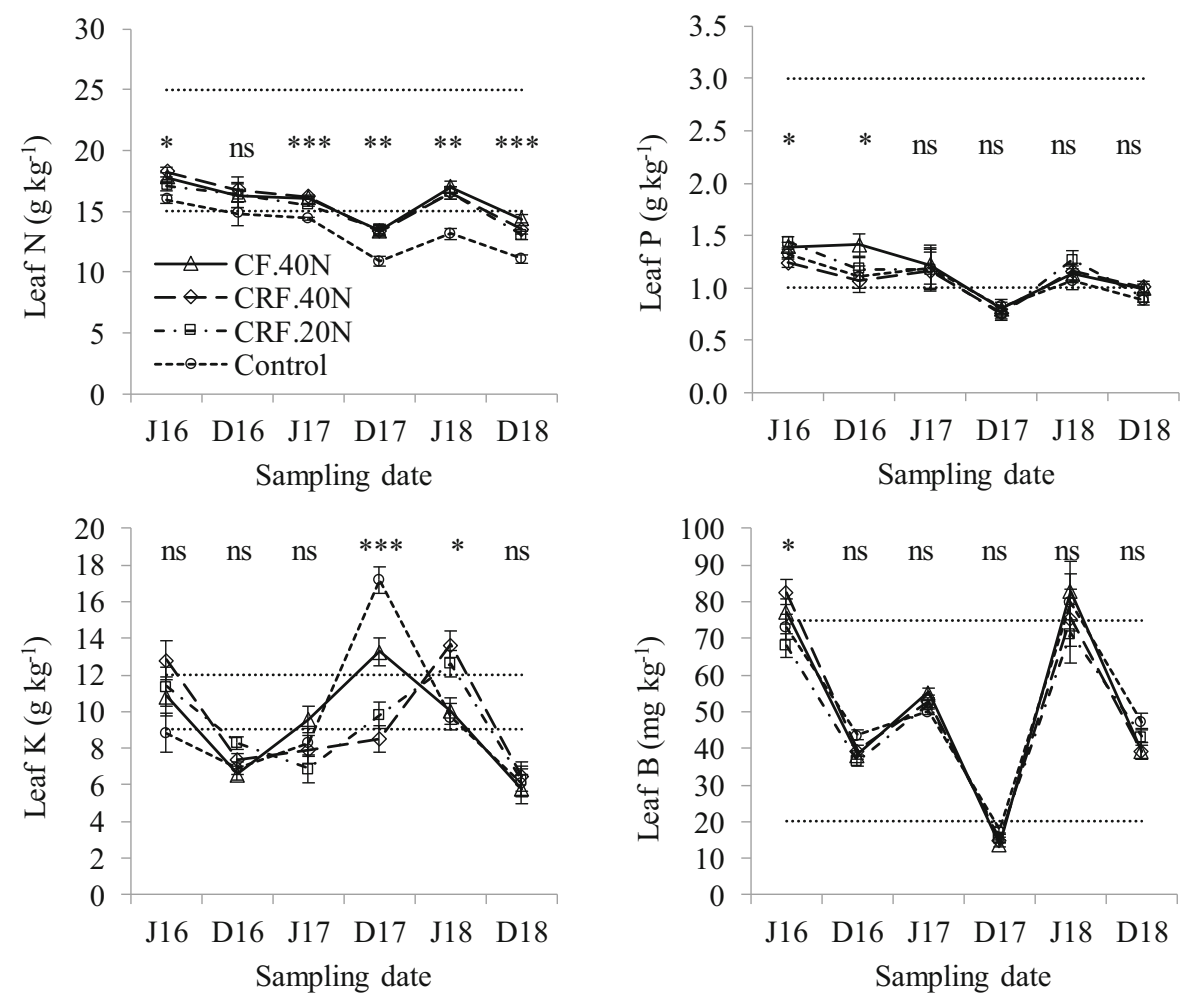
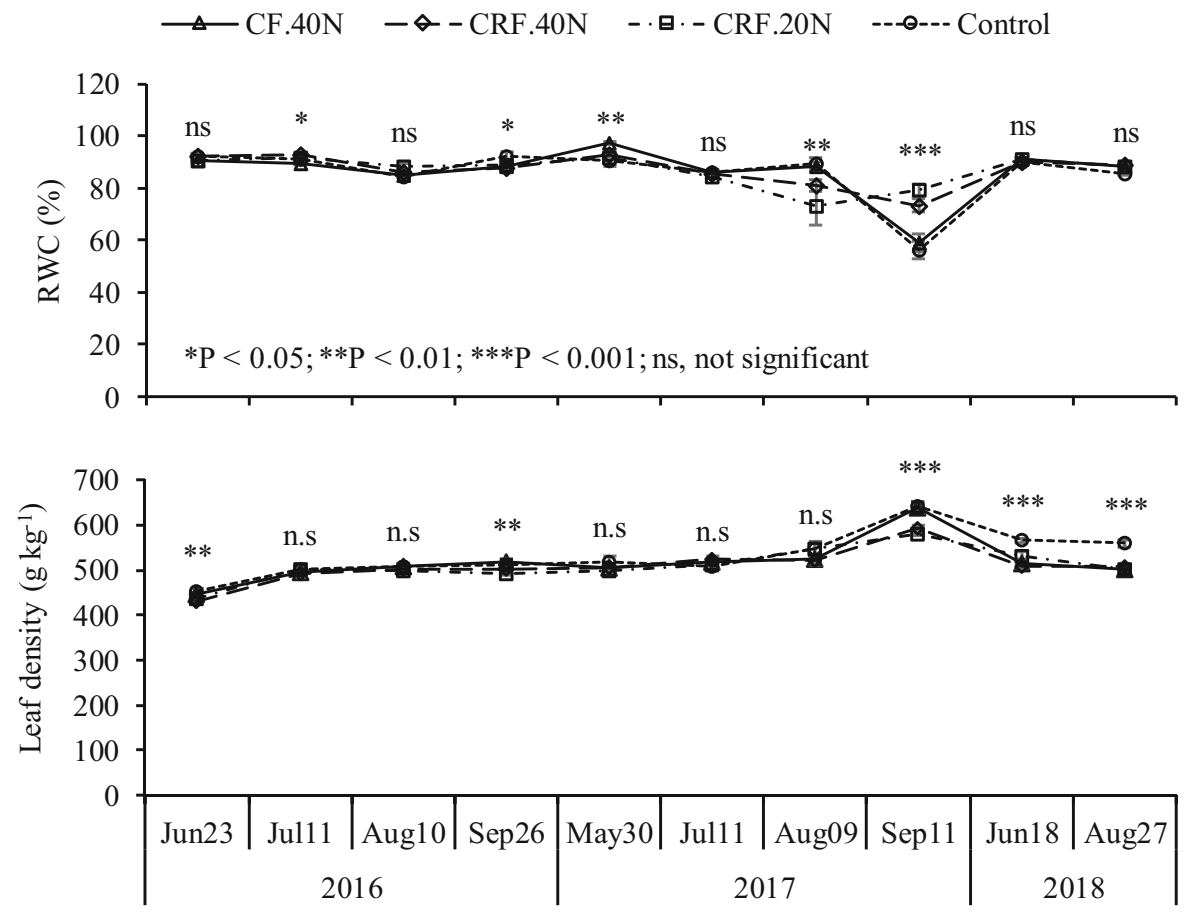

Fig. 4 Relative water content (RWC) and leaf density response to conventional fertilizer ( $\mathrm{CF}$ ) and to controlled-release fertilizer (CRF) applied at the rates of 0 (Control), $20(20 \mathrm{~N})$ and $40(40 \mathrm{~N}) \mathrm{kg} \mathrm{N} \mathrm{ha}^{-1}$. ns (not significant), $* *(\mathrm{P}<0.01)$ and $* * *(\mathrm{P}<0.001)$ are the results of analysis of variance 
Fig. 5 Net photosynthetic rate $(\mathrm{A})$, stomatal conductance to water vapour $\left(\mathrm{g}_{\mathrm{s}}\right)$, intrinsic water use efficiency $\left(\mathrm{A} / \mathrm{g}_{\mathrm{s}}\right)$ and ratio of intercellular to atmospheric $\mathrm{CO}_{2}$ concentration $\left(\mathrm{C}_{\mathrm{i}} / \mathrm{C}_{\mathrm{a}}\right)$ response to conventional fertilizer $(\mathrm{CF})$ and to controlled-release fertilizer (CRF) applied at the rates of 0 (Control), $20(20 \mathrm{~N})$ and $40(40 \mathrm{~N}) \mathrm{kg} \mathrm{N} \mathrm{ha}^{-1}$. ns (not significant $), *(\mathrm{P}<0.05)$, $* *(\mathrm{P}<0.01)$ and $* * *(\mathrm{P}<0.001)$ are the results of analysis of variance
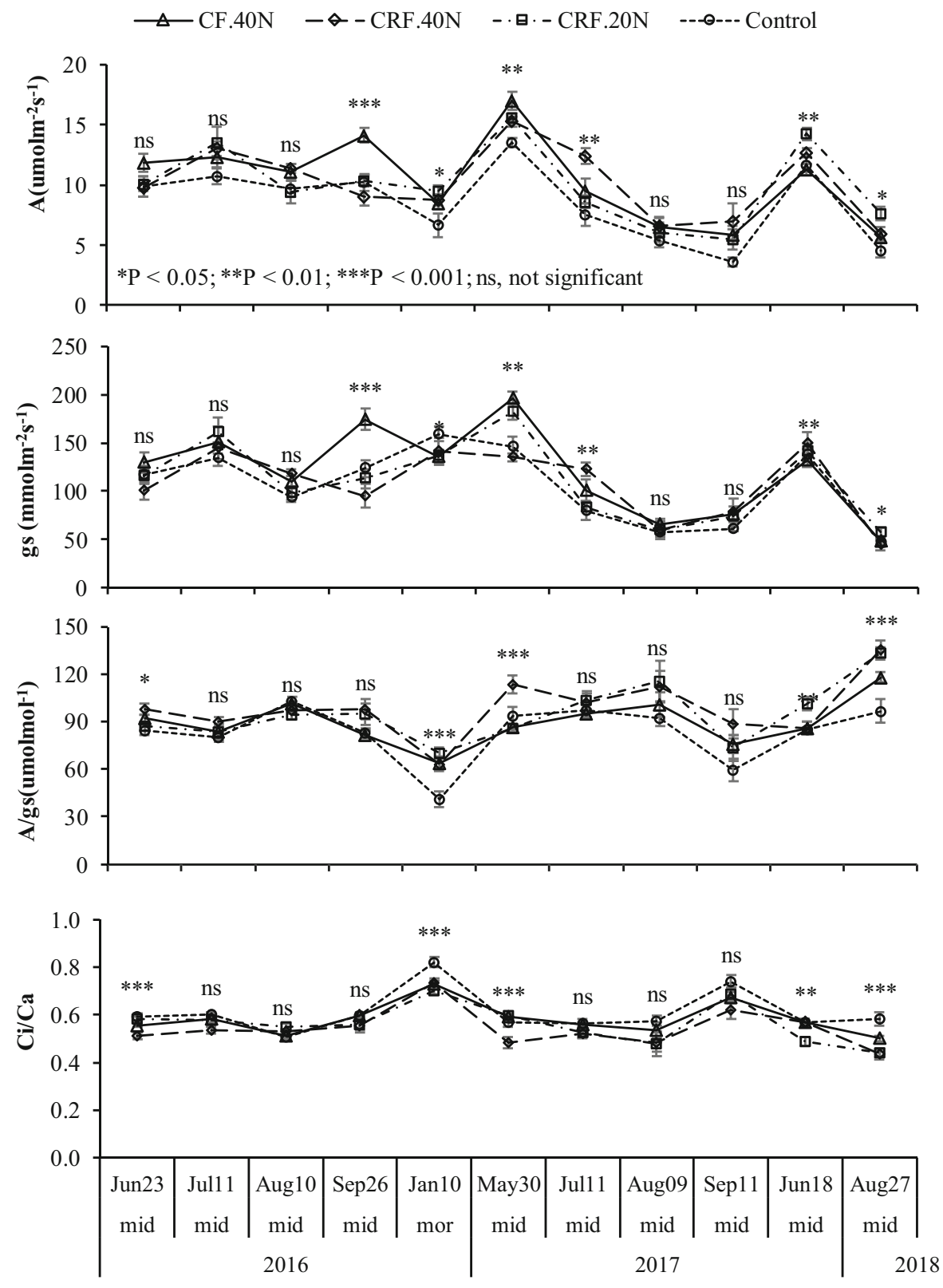

(Table 1). Meanwhile, as the concentration of total carotenoids was not affected by the applied treatments, the $\mathrm{Chl}(\mathrm{a}+\mathrm{b}) / \mathrm{Car}$ ratio was also lower in unfertilized treatment.

\section{Soil properties}

Some important soil properties, such as extractable $\mathrm{P}$ and $\mathrm{K}$, all the exchangeable bases and cation-exchange capacity did not vary significantly between fertilizer treatments, whereas soil $\mathrm{pH}\left(\mathrm{H}_{2} \mathrm{O}\right)$ was significantly higher in the control treatment in comparison to all the others (data not shown). Easily oxidizable $\mathrm{C}$ was significantly higher in CRF.40 N $\left(6.6 \mathrm{~g} \mathrm{~kg}^{-1}\right)$ and CRF.20 N (6.4 $\left.\mathrm{g} \mathrm{kg}^{-1}\right)$ treatments in comparison to the unfertilized control $\left(4.7 \mathrm{~g} \mathrm{~kg}^{-1}\right)$ (Fig. 6). The CF treatment gave lower and higher average values than the CRF treatments and the control, respectively, but without significant differences to any of them. Kjeldahl $\mathrm{N}$ was significantly higher in CRF.40 N 
Table 1 Leaf biochemical analyses after the application of a conventional fertilizer (CF) and a controlled-release fertilizer (CRF) applied at the rates of 0 (Control), $20(20 \mathrm{~N})$ and $40(40 \mathrm{~N}) \mathrm{kg} \mathrm{N} \mathrm{ha}^{-1}$

\begin{tabular}{|c|c|c|c|c|c|c|}
\hline & Year & CF.40 N & CRF.40 N & CRF.20 N & Control & Significance \\
\hline \multirow[t]{3}{*}{$\mathrm{Chl}_{(\mathrm{a}+\mathrm{b})}$} & 2016 & $2.90 \pm 0.22^{\mathrm{ab}}$ & $3.11 \pm 0.14^{\mathrm{a}}$ & $3.09 \pm 0.24^{\mathrm{a}}$ & $2.43 \pm 0.15^{b}$ & $*$ \\
\hline & 2017 & $2.53 \pm 0.07^{\mathrm{a}}$ & $2.58 \pm 0.04^{\mathrm{a}}$ & $2.48 \pm 0.08^{\mathrm{a}}$ & $2.05 \pm 0.06^{\mathrm{b}}$ & $* *$ \\
\hline & 2018 & $2.43 \pm 0.05^{\mathrm{a}}$ & $2.36 \pm 0.06^{\mathrm{a}}$ & $2.33 \pm 0.07^{\mathrm{a}}$ & $1.89 \pm 0.05^{\mathrm{b}}$ & $* *$ \\
\hline \multirow[t]{3}{*}{ Car } & 2016 & $0.658 \pm 0.038$ & $0.653 \pm 0.028$ & $0.645 \pm 0.051$ & $0.580 \pm 0.027$ & ns \\
\hline & 2017 & $0.546 \pm 0.023$ & $0.540 \pm 0.028$ & $0.539 \pm 0.016$ & $0.502 \pm 0.037$ & ns \\
\hline & 2018 & $0.551 \pm 0.017$ & $0.544 \pm 0.019$ & $0.533 \pm 0.026$ & $0.505 \pm 0.031$ & ns \\
\hline \multirow[t]{3}{*}{$\mathrm{Chl}_{(\mathrm{a}+\mathrm{b})} / \mathrm{Car}$} & 2016 & $4.40 \pm 0.13^{\mathrm{ab}}$ & $4.76 \pm 0.02^{\mathrm{a}}$ & $4.78 \pm 0.04^{\mathrm{a}}$ & $4.18 \pm 0.12^{\mathrm{b}}$ & $* *$ \\
\hline & 2017 & $4.62 \pm 0.06^{\mathrm{a}}$ & $4.74 \pm 0.08^{\mathrm{a}}$ & $4.58 \pm 0.10^{\mathrm{a}}$ & $4.07 \pm 0.07^{\mathrm{b}}$ & $* *$ \\
\hline & 2018 & $4.42 \pm 0.04^{\mathrm{a}}$ & $4.33 \pm 0.05^{\mathrm{a}}$ & $4.37 \pm 0.08^{\mathrm{a}}$ & $3.73 \pm 0.06^{\mathrm{b}}$ & $* * *$ \\
\hline \multirow[t]{3}{*}{ TSP } & 2016 & $3.47 \pm 0.29$ & $3.67 \pm 0.34$ & $2.92 \pm 0.23$ & $2.88 \pm 0.20$ & ns \\
\hline & 2017 & $2.83 \pm 0.17^{\mathrm{a}}$ & $2.77 \pm 0.20^{\mathrm{a}}$ & $2.53 \pm 0.12^{\mathrm{ab}}$ & $2.23 \pm 0.12^{\mathrm{b}}$ & $*$ \\
\hline & 2018 & $2.77 \pm 0.08^{\mathrm{a}}$ & $2.81 \pm 0.12^{\mathrm{a}}$ & $2.50 \pm 0.22^{\mathrm{a}}$ & $1.83 \pm 0.11^{\mathrm{b}}$ & $* *$ \\
\hline \multirow[t]{3}{*}{ TSS } & 2016 & $97.9 \pm 2.5^{\mathrm{a}}$ & $94.2 \pm 3.1^{\mathrm{a}}$ & $92.9 \pm 3.0^{\mathrm{a}}$ & $82.5 \pm 1.5^{\mathrm{b}}$ & $* * *$ \\
\hline & 2017 & $116.3 \pm 5.7^{\mathrm{a}}$ & $110.3 \pm 2.3^{\mathrm{a}}$ & $112.9 \pm 1.9^{\mathrm{a}}$ & $97.5 \pm 3.8^{\mathrm{b}}$ & $* *$ \\
\hline & 2018 & $96.1 \pm 2.2^{\mathrm{a}}$ & $99.8 \pm 3.7^{\mathrm{a}}$ & $91.4 \pm 5.2^{\mathrm{a}}$ & $75.9 \pm 2.5^{\mathrm{b}}$ & $* *$ \\
\hline
\end{tabular}

Total chlorophylls $\left(\mathrm{Chl}(a+b), \mathrm{mg} \mathrm{g}^{-1} \mathrm{DW}\right)$, total carotenoids (Car, $\left.\mathrm{mg} \mathrm{g}^{-1} \mathrm{DW}\right)$, ratio Chl $(a+b) /$ Car, total soluble proteins (TSP, $\mathrm{mg} \mathrm{g}^{-1} \mathrm{DW}$ ) and total soluble sugars (TSS, $\mathrm{mg} \mathrm{g}^{-1} \mathrm{DW}$ ) concentrations. For each trait and year, means followed by the same letter are not significantly different by Tukey HSD multiple range test $(\alpha=0.05)$

$\left(0.79 \mathrm{~g} \mathrm{~kg}^{-1}\right)$ and CRF.20 N $\left(0.74 \mathrm{~g} \mathrm{~kg}^{-1}\right)$ treatments than in the CF.40 N $\left(0.45 \mathrm{~g} \mathrm{~kg}^{-1}\right)$ and control $\left(0.31 \mathrm{~g} \mathrm{~kg}^{-1}\right)$ treatments. Inorganic $\mathrm{N}$ showed the same pattern observed for easily oxidizable $\mathrm{C}$ and kjeldahl N. CRF.40 N showed the higher values and the control treatment the lower ones. The CF.40 N treatment displayed average lower values than the CRF.40 N treatment, despite no significant differences between them were found. Easily oxidizable $\mathrm{C}$, kjeldahl $\mathrm{N}$ and inorganic $\mathrm{N}$ were significantly higher in the soil surface $0-0.1 \mathrm{~m}$ layer than in the deeper $0.1-0.2 \mathrm{~m}$ soil layer.

Easily extractable and total glomalin showed significant differences between treatments (Fig. 7). The higher values were found in CRF.40 N (1.41 and $2.04 \mathrm{mg} \mathrm{g}^{-1}$, respectively) treatment and the lower ones in the CF.40 N treatment ( 0.88 and $0.92 \mathrm{mg} \mathrm{g}^{-1}$, respectively). The surface layer also showed higher EE-GRSP and T-GRSP than the deeper layer.

\section{Discussion}

CRF failed to improve tree crop growth and yield

Olive yield, pruning wood and canopy volume increased from the control to the higher $\mathrm{N}$ fertilized treatments. The data stressed the positive effect of $\mathrm{N}$ rate but showed no effect of the mechanism of delaying the availability of $\mathrm{N}$ in the soil over the $\mathrm{CF}$. A positive effect of $\mathrm{N}$ rate on the growth and yield of olive (Erel et al. 2008; Rodrigues et al. 2011; Ferreira et al. 2020) as well as on several other fruit crops (Arrobas et al. 2019; Chater et al. 2020; Vashisth and Kadyampakeni 2020) has been frequently found. The effect of CRF on plant growth and yield have been much more inconsistent. In potted or containerized plants, young plantations or paddy fields, positive results on plant growth or $\mathrm{N}$ use efficiency are often observed (Adams et al. 2017; Ke et al. 2017; Chu et al. 2019), but in field trials it has been also common to not find relevant advantages from the use of CRF (Guertal. 2000; Rodrigues et al. 2010; Chilundo et al. 2016). The release of $\mathrm{N}$ in this CRF is regulated by coatings of ammonium sulphate and polyurethane, which means 

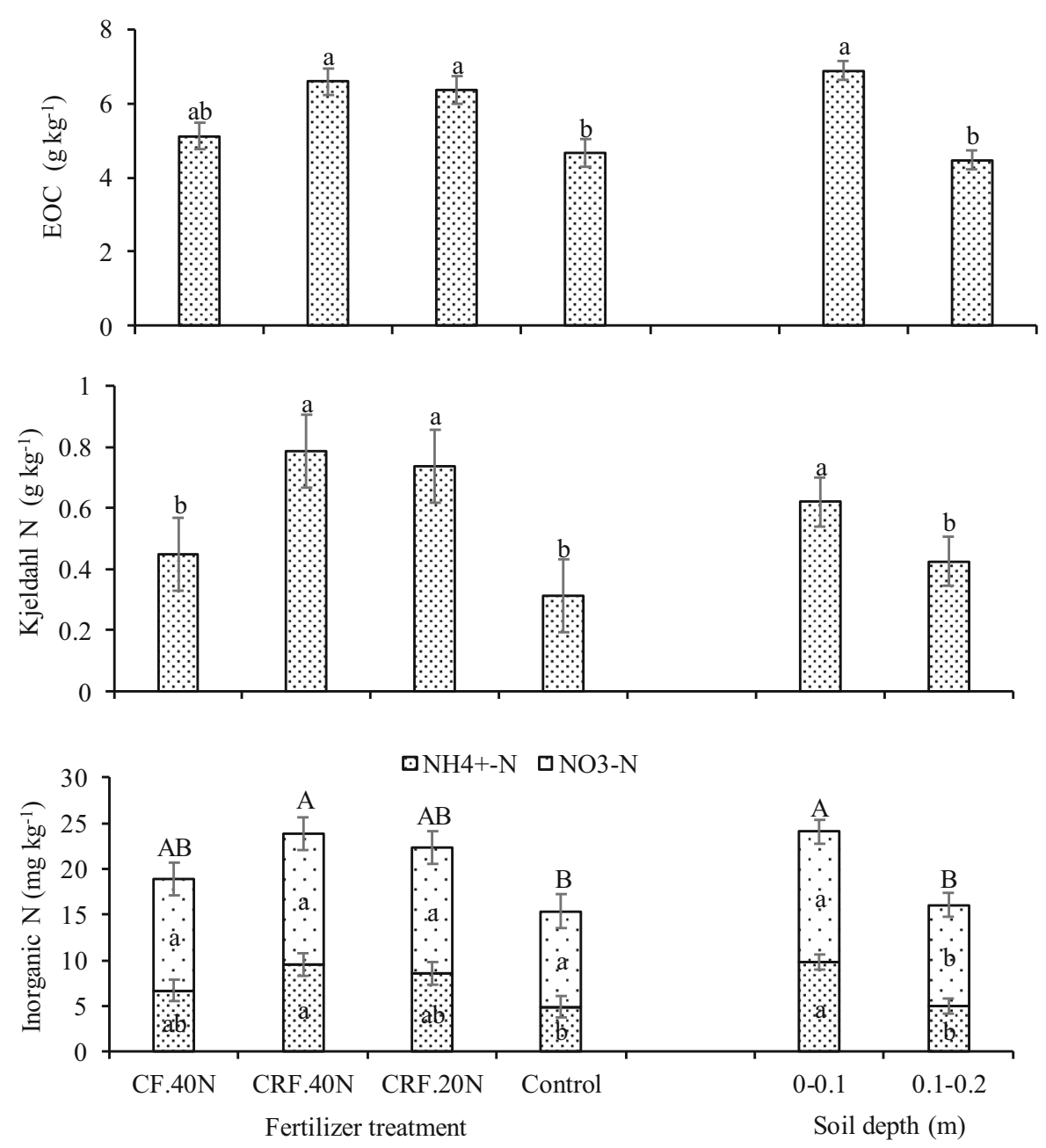

Fig. 6 Easily oxidizable carbon (EOC), kjeldahl nitrogen (N) and inorganic $\mathrm{N}$ as a function of fertilizer treatment and soil depth. Means associated to the same letter are not significantly different by Tukey HSD test $(\alpha=0.05)$. Capital letter is the result of Tukey HSD test for total inorganic $\mathrm{N}$ $\left(\mathrm{NO}_{3}{ }^{-}-\mathrm{N}+\mathrm{NH}_{4}{ }^{+}-\mathrm{N}\right)$. Vertical bars are standard errors

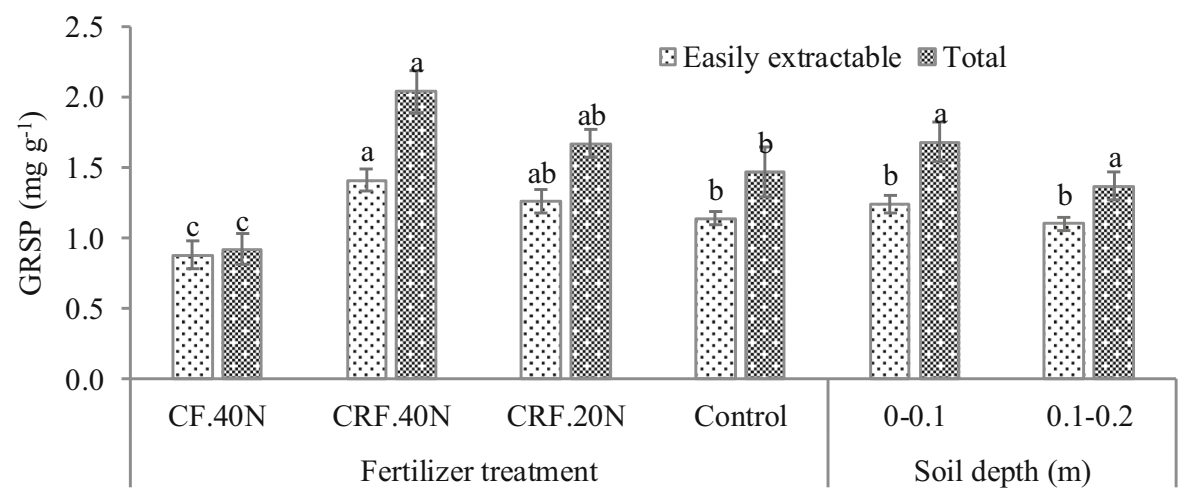

Fig. 7 Glomalin-related soil proteins (GRSP) as a function of fertilizer treatment and soil depth. Means associated to the same letter are not significantly different by Tukey HSD test $(\alpha=0.05)$. Vertical bars are standard errors 
that the rate of release is dependent of microbial, physical and chemical processes (Trenkel et al. 2010). It seems that in this particular agro-system, the delay in $\mathrm{N}$ release associated to the $\mathrm{CRF}$ was not sufficient to cause a significant difference in olive yield. It is noteworthy that the effect of controlled release of this product ceases in three months and also that part of the $\mathrm{N}$ is not under any protection mechanism, being ready for absorption after the application of the fertilizer in the soil.

$\mathrm{N}$ rate, but not fertilizer type, increased the nutritional status and the photosynthetic performance of trees

The fertilizer type did not influence significantly the nutritional status of the trees, but leaf $\mathrm{N}$ concentration decreased over the experimental period in all the treatments. In the control treatment, the values decreased to the lower limit of the sufficiency range, as established for this species (Fernández-Escobar 2017), which stresses the role of $\mathrm{N}$ in olive yield and tree crop growth, as above mentioned. The decrease in leaf $\mathrm{N}$ concentrations in all the treatments during the experimental period was probably due to the youth of the trees. Young 16-year-old trees, rainfed managed, are still growing, so they should receive increasing rates of $\mathrm{N}$, which was not done in this study to maintain the experimental protocol. But it seems clear that the farmer should use more than $40 \mathrm{~kg} \mathrm{~N} \mathrm{ha}^{-1}$ in following seasons.

$\mathrm{N}$ deprivation resulted in a marked decrease of photosynthetic rate due to higher stomatal and biochemical limitations, as evidenced by the variations of $\mathrm{g}_{\mathrm{s}}, \mathrm{A} / \mathrm{g}_{\mathrm{s}}$ and $\mathrm{C}_{\mathrm{i}} / \mathrm{C}_{\mathrm{a}}$ data, as well as by the influence in light-harvesting capacity, as demonstrated by chlorophylls concentrations. Similar influence of $\mathrm{N}$ was reported to other tree species and ecological conditions (Boussadia et al. 2010; Wu et al. 2018). Furthermore, as $\mathrm{N}$ is also involved in cell walls, which play a role in mesophyll conductance $\left(g_{m}\right)$, and as $g_{m}$ is generally lower in leaves with greater leaf density (Adachi et al 2013), it may be assumed that the photosynthetic responses to $\mathrm{N}$ shortage were also related with limitations to $\mathrm{CO}_{2}$ diffusion in the leaf liquid phase induced by the higher leaf density. Nonetheless, leaves with higher density are better adapted to survive periods of severe drought, which are common in the region, due to higher resistance to physical damage by desiccation, and, therefore, greater leaf toughness should enhance leaf lifespan, maximizing $\mathrm{C}$ assimilation. Meanwhile, the results are consistent with previous studies mostly reporting none or positive effects of $\mathrm{N}$-supply on water use efficiency (Li et al. 2003; Gong et al. 2011).

As photosynthesis decreased under $\mathrm{N}$ deprivation, an excess of reducing power is frequently generated and thus, over-reduction of photosynthetic electron chain may result in the generation of reactive oxygen species (ROS) that can cause oxidative damage. In fact, leaves grown under $\mathrm{N}$ shortage revealed signs of oxidative stress, as confirmed by the reduction of chlorophyll and total soluble protein concentrations, meaning that the antioxidative system and cellular redox balance are susceptible to disruption without $\mathrm{N}$ application. Similar results were observed in previous studies (Correia et al. 2005; Ding et al. 2005). Furthermore, total carotenoids concentration was not significantly different between treatments, chlorophylls/carotenoids ratio was significantly lower in the control than in the fertilized plants. Since carotenoids play an important role in photoprotection, scavenging ROS and releasing the excess energy by thermal dissipation via xanthophyll cycle (Lisar et al. 2012), this lower ratio indicates higher need for photoprotection of chlorophylls. On the other hand, as unfertilized plants had lower sink capacity, the observed drop of total soluble sugars concentration indicates that the main response is mediated by lower net photosynthetic rate. Thus, $\mathrm{N}$-stressed trees will present additional negative effects since soluble sugars are sources of $\mathrm{C}$ for maintenance and growth processes, may act as osmoprotectants and are also involved in detoxification of ROS and stabilization of cellular macromolecules structures (Lisar et al. 2012).

\section{CRF improved important soil properties}

Most soil properties were not significantly influenced by the treatments. $\mathrm{pH}$ however, was higher in the control treatment. Urea and ammonium fertilizers may lead to soil acidification through the nitrification reactions (Neumann and Römheld 2012), which may help to explain the lower $\mathrm{pH}$ in fertilized treatments. On the other hand, the samples were taken in the autumn shortly after the first rains. Soil moisture allows the restart of the mineralization of organic substrates after the long summer. Fertilized treatments 
may have originated increased amount of residues in the soil, by stimulating weed growth, which increases mineralization activity leading to increased acidify of the soil (Havlin et al. 2014).

Soil organic $\mathrm{C}$ in CRF treatments was significantly higher than in the control and the average value higher than in $\mathrm{CF}$ treatment. Kjeldahl $\mathrm{N}$, in turn, was significantly higher in CRF treatments than in $\mathrm{CF}$ and control treatments. This clear evidence of the increase of the pools of organic $\mathrm{C}$ and $\mathrm{N}$ is due to the increased addition of new organic materials in CRF treatments. The $\mathrm{CF}$ in which $\mathrm{N}$ is readily available after application, in early spring, could enhance weeds growth immediately after application much more than the CRF. However, under this ground management system, herbicide application is performed shortly after fertilizers application, which greatly restrict the potential effect of soil available $\mathrm{N}$ on soil $\mathrm{C}$ input through weeds development. It is well known that the ground management systems restricting the growth of weeds, such as those using conventional tillage or herbicides, lead low levels of soil organic matter (Rodrigues and Arrobas 2020). In contrast, N from CRF is not fully available in spring and in summer drought conditions make it difficult to be taken up efficiently. Thus, it is expected that in the next autumn more mineral $\mathrm{N}$ can persist in the soil, playing an increased role in weeds development, since the herbicide that was used (glyphosate) has no residual effect. This extra mineral $\mathrm{N}$ might have been responsible for the increase of the pools of $\mathrm{C}$ and $\mathrm{N}$ found in the soil. Despite in this experimental protocol no measurements were scheduled to assess the growth of weeds, the results of soil mineral $\mathrm{N}$ corroborate the thesis, since the values were higher in the CRF.40 N treatment and comparable to those found in other crops where higher $\mathrm{N}$ rates were applied in spring (Rodrigues et al. 2021). Furthermore, as weeds start development as early as the first rains, and excess precipitation only tends to appear in the middle of winter, it seems that they can act as a catch crop, commonly used in arable crops (Rodrigues et al. 2002; Notaris et al. 2018), reducing the risk of nitrate leaching from the CRF plots.

The higher values of GRSP, which are a product of mycorrhizal fungi (Gispert et al. 2017; Nautiyal et al. 2019), in CRF treatments can also be associated to an increased weed growth and/or to more activity of olive roots in the autumn. This positive association of GRSP to soil organic $\mathrm{C}$ mays suggests that all these traits are probably subjected to similar deposition and decomposition dynamics, as reported by Yang et al. (2017). GRSP play an important role in soil physical properties, enhancing the stability of aggregates and improving soil porosity (Yang et al. 2017; Nautiyal et al. 2019), which may mean that promoting biological activity in the autumn may have multiple long-term benefits, such as the increase of organic matter and the reduction of soil erosion.

One might think that the most relevant factor in the availability of some inorganic $\mathrm{N}$ in the soil in the autumn would be the risk of nitrate leaching. However, this study shows evidence to the contrary, that this can bring environmental benefits in the long-term, such as the increase of soil organic matter and also the reduction of soil erosion provided by weeds. Polyurethane and other polymeric materials used for fertilizers encapsulation still present environmental problems due to the persistence in the soil and their xenobiotic nature (Trenkel 2010). However, in the CRF used in this study, only $26.3 \% \mathrm{~N}$ is polyurethane coated urea, and only $40 \mathrm{~kg} \mathrm{~N} \mathrm{ha}^{-1}$ were annually applied. Probably the environmental benefits mentioned above, can compensate for this aspect normally seen as negative in this type of fertilizers.

\section{Conclusions}

CRF seemed to show some advantages over the CF, but by an unexpected effect. Not in a direct way, by improving the performance of the trees, but in enhancing soil fertility. The CRF treatments showed higher levels of inorganic $\mathrm{N}$ in the soil by autumn. An aspect that at the outset could be interpreted as negative, since it could lead to $\mathrm{N}$ loss by leaching, proved to be a factor that may be behind the increase in the organic $\mathrm{C}$, kjeldahl $\mathrm{N}$ and GRSP, which can be due to a stimulus in weed development and an eventual increase in the root activity of the trees. Thus, the availability of soil inorganic- $\mathrm{N}$ in the autumn, in a climate in which excess precipitation and the risk of leaching usually only occur in winter, led to weeds growth that seem to act as a catch crop, capturing residual inorganic N. Additionally, they contribute to protect the soil from erosion and to increase soil organic matter, aspects that can benefit the agrosystem in the long-term. 
Funding Doctoral fellowship under the Doctoral Program "Agricultural Production Chains-from fork to farm" (PD/ 00122/2012) provided by the FCT-Portuguese Foundation for Science and Technology to E. Silva (PD/BD/128274/2017). This research was funded by the Foundation for Science and Technology (FCT, Portugal) and FEDER under Programme PT2020 for financial support to CIMO (UIDB/00690/2020) and CITAB (UIDB/04033/2020). The research was integrated in the activities of the Operational Group "Novas práticas em olivais de sequeiro: estratégias de mitigação e adaptação às alterações climáticas", funded by PT2020 and EAFRD (European Agricultural Fund for Rural Development).

\section{Decalarations}

Conflict of interest The authors declare that they have no conflict of interest.

\section{References}

Adachi S, Nakae T, Uchida M, Soda K, Takai T, Oi T, Yamamoto T, Ookawa T, Miyake H, Yano M, Hirasawa T (2013) The mesophyll anatomy enhancing $\mathrm{CO}_{2}$ diffusion is a key trait for improving rice photosynthesis. J Exp Bot 64:1061-1072. https://doi.org/10.1093/jxb/ers382

Adams PR, Musk R, Blake R (2017) Establishing Eucalyptus nitens plantations using controlled-release fertilisers. Aust For 80:309-316. https://doi.org/10.1080/00049158.2017. 1387995

Arnon DI (1949) Copper enzymes in isolated chloroplasts polyphenoloxidase in beta vulgaris. Plant Physiol 24:1-15. https://doi.org/10.1104/pp.24.1.1

Arrobas M, Parada MJ, Magalhães P, Rodrigues MA (2011) Nitrogen-use efficiency and economic efficiency of slowrelease $\mathrm{N}$ fertilisers applied to irrigated turfs in a Mediterranean environment. Nutr Cycl Agroecosys 89:329-339

Arrobas M, Santos D, Ribeiro A, Pereira E, Rodrigues MA (2019) Soil and foliar nitrogen and boron fertilization of almond trees grown under rainfed conditions. Eur J Agron 106:39-48. https://doi.org/10.1016/j.eja.2019.02.014

Baird RB, Eaton AD, Rice EW (2017) Nitrate by ultraviolet spectrophotometric method. In: Baird RB, Eaton AD, Rice EW (eds) Standard methods for the examination of water and wastewater. American Public Health Association, American Water Works Association, Water Environment Federation: Washington, DC.

Boussadia O, Steppe K, Zgallai H, Ben El Hadj S, Braham M, Lemeur R, Van Labeke MC (2010) Effects of nitrogen deficiency on leaf photosynthesis, carbohydrate status and biomass production in two olive cultivars 'Meski' and 'Koroneiki.' Sci Hortic 123:336-342. https://doi.org/10. 1016/j.scienta.2009.09.023

Bradford MM (1976) A rapid and sensitive method for the quantitation of microgram quantities of protein utilizing the principle of protein-dye binding. Anal Biochem
72:248-254.

https://doi.org/10.1016/0003-

\section{7(76)90527-3}

Brito C, Dinis LT, Luzio A, Silva E, Gonçalves E, Meijón M, Escandón M, Arrobas M, Rodrigues MA, Moutinho-Pereira J, Correia CM (2019) Kaolin and salicylic acid alleviate summer stress in rainfed olive orchards by modulation of distinct physiological and biochemical responses. Sci Hortic 246:201-211. https://doi.org/10. 1016/j.scienta.2018.10.059

Campos I, Guerra J, Ferreira JG, Schmidt L, Alves F, Vizinho A, Lopes GP (2017) Understanding climate change policy and action in Portuguese municipalities: a survey. Land Use Policy 62:68-78. https://doi.org/10.1016/j.landusepol. 2016.12.015

Carvalho A, Schmidt L, Santos FD, Delicado A (2014) Climate change research and policy in Portugal. Wiley Interdiscip Rev Clim Chang 5:199-217. https://doi.org/10.1002/wcc. 258

Chater JM, Merhaut DJ, Preece JE (2020) Diagnosis and management of nutrient constraints in pomegranate. In: Srivastava $\mathrm{AK}, \mathrm{Hu} \mathrm{C}$ (eds) Fruit crops: diagnosis and management of nutrient constraints. Elsevier, The Netherlands, pp 681-691

Chilundo M, Joel A, Wesström I, Brito R, Messing I (2016) Effects of reduced irrigation dose and slow release fertiliser on nitrogen use efficiency and crop yield in a semi-arid loamy sand. Agric Water Manag 168:68-77. https://doi. org/10.1016/j.agwat.2016.02.004

Chu X, Wang X, Zhang D, Wu X, Zhou Z (2019) Responses of Taxus chinensis and Phoebe chekiangensis seedlings to controlled release fertilizer in various formulations and application rates. iForest 12:254-261. https://doi.org/10. 3832/ifor2714-012

Correia C, Rodrigues MA (2020) Alterações climáticas e degradação do solo no interior de Portugal: um cocktail explosivo para as culturas perenes. AGROTEC 36:4-7

Correia CM, Moutinho-Pereira JM, Coutinho JF, Björn LO, Torres-Pereira JMG (2005) Ultraviolet-B radiation and nitrogen affect the photosynthesis of maize: a Mediterranean field study. Eur J Agron 22:337-347. https://doi. org/10.1016/j.eja.2004.05.002

Coyne MS (2008) Biological denitrification. In: Schepers JS, Raun WR (eds) Nitrogen in agricultural Systems, Agron. Monographs 49, ASA, CSSA, SSSA, Madison, WI, pp 201-253

Ding L, Wang KJ, Jiang GM, Biswas DK, Xu H, Li LF, Li YH (2005) Effects of nitrogen deficiency on photosynthetic traits of maize hybrids released in different years. Ann Bot 96(5):925-930. https://doi.org/10.1093/aob/mci244

EIDT (Estratégia Integrada de Desenvolvimento Territorial) (2015) Estratégia integrada de desenvolvimento territorial - Terras de Trás-os-Montes. Comunidade Intermunicipal, Terras de Trás-os-Montes, Portugal.

Emilsson T, Berndtsson JC, Mattsson JE, Rolf K (2007) Effect of using conventional and controlled release fertilizers on nutrient runoff from various vegetated roof systems. Ecol Eng 29:260-271

Erel R, Dag A, Ben-Gal A, Schwartz A, Yermiyahu U (2008) Flowering and fruit set of olive trees in response to nitrogen, phosphorus, and potassium. J Am Soc Hortic Sci 133:639-647 
Fernández-Escobar R (2017) Fertilization. In: Barranco D, Fernández-Escobar R, Rallo L (eds) El cultivo del olivo, 7th edn. Mundi-Prensa, Madrid, Spain, pp 419-460

Ferreira IQ, Arrobas M, Claro AM, Rodrigues MA (2013) Soil management in rainfed olive orchards may result in conflicting effects on olive production and soil fertility. Span J Agric Res 11(2):472-480

Ferreira IQ, Arrobas M, Moutinho-Pereira JM, Correia CM, Rodrigues MA (2020) The effect of nitrogen applications on the growth of young olive trees and nitrogen use efficiency. Turk J Agric For 44:278-289. https://doi.org/10. 3906/tar-1905-26

Fraga H, Atauri IGC, Malheiro AC, Moutinho-Pereira J, Santos JA (2017) Viticulture in Portugal: a review of recent trends and climate change projections. OENO One 51(2):61-69

Gispert M, Pardini G, Emran M, Doni S, Masciandaro G (2017) Seasonal evolution of soil organic matter, glomalin and enzymes and potential for $\mathrm{C}$ storage after land abandonment and renaturalization processes in soils of NE Spain. CATENA 162:402-413. https://doi.org/10.1016/j.catena. 2017.10.019

Gong XY, Chen Q, Lin S, Brueck H, Dittert K, Taube F, Schnyder H (2011) Tradeoffs between nitrogen-and water-use efficiency in dominant species of the semiarid steppe of Inner Mongolia. Plant Soil 340:227-238. https://doi.org/ 10.1007/s11104-010-0525-9

Guertal EA (2000) Preplant slow-release nitrogen fertilizers produce similar bell pepper yields as split applications of soluble fertilizers. Agron J 92:388-393

Havlin JL, Tisdale SL, Nelson WL, Beaton JD (2014) Soil fertility and fertilizers, an introduction to nutrient management, 8th edn. Pearson, Boston, USA

Houba VJ, van der Lee JJ, Novozamsky I, Walinga I (1997) Soil and plant analysis. In: Part 5. Soil analysis procedure. Wageningen Agricultural University, The Netherlands.

Irigoyen JJ, Einerich DW, Sanchez-Díaz M (1992) Water stress induced changes in concentrations of proline and total soluble sugars in nodulated alfalfa (Medicago sativa) plants. Physiol Plant 84:55-60. https://doi.org/10.1111/j. 1399-3054

Ke J, Xing X, Li G, Ding Y, Dou F, Wang S, Liu Z, Tang S, Ding C, Chen L (2017) Effects of different controlled-release nitrogen fertilisers on ammonia volatilisation, nitrogen use efficiency and yield of blanket-seedling machine-transplanted rice. Field Crops Res 205:147-156. https://doi.org/ 10.1016/j.fcr.2016.12.027

Li F, Kang S, Zhang J, Cohen S (2003) Effects of atmospheric $\mathrm{CO}_{2}$ enrichment, water status and applied nitrogen on water- and nitrogen-use efficiencies of wheat. Plant Soil 254:279-289. https://doi.org/10.1023/A:1025521701732

Lichtenthaler HK (2007) Differences in pigment composition, photosynthetic rates and chlorophyll fluorescence images of sun and shade leaves of four tree species. Plant Physiol Biochem 45:577-588. https://doi.org/10.1016/j.plaphy. 2007.04.006

Lisar SYS, Motafakkerazad R, Hossain MM, Rahman IMM (2012) Water Stress in Plants: Causes, Effects and Responses. In Water Stress, Ismail Md. Mofizur Rahman and Hiroshi Hasegawa, IntechOpen, DOI: https://doi.org/ $10.5772 / 39363$
Marschner P, Rengel Z (2012) Nutrient availability in soils. In: Marschner P (ed) Marschner's mineral nutrition of higher plants, 3rd edn. Academic Press (Elsevier), MA, USA, pp 315-330

Mulla DJ, Strock JS (2008) Nitrogen transport processes in soil. In: Schepers JS, Raun WR (eds) Nitrogen in agricultural systems, Agron. Monographs 49, ASA, CSSA, SSSA, Madison, WI, pp 361-400

Nautiyal P, Rajput R, Pandey D, Arunachalam K, Arunachalam A (2019) Role of glomalin in soil carbon storage and its variation across land uses in temperate Himalayan regime. Biocatal Agric Biotechnol 21:101311. https://doi.org/10. 1016/j.bcab.2019.101311

Navarro C, Hidalgo J, Campo MG (2017) Sistemas de plantación. In: Barranco D, Fernandez-Escobar R, Rallo L (eds) El cultivo del olivo, 7 th edn. Mundi-Prensa, Madrid, Spain, pp 289-334

Neumann G, Römheld V (2012) Rhizosphere in relation to plant nutrition. In: Marschner P (ed) Marschner's mineral nutrition of higher plants, 3rd edn. Academic Press (Elsevier), MA, USA, pp 347-368

Notaris C, Rasmussen J, Sorensen P, Olesen JE (2018) Nitrogen leaching: a crop rotation perspective on the effect of $\mathrm{N}$ surplus, field management and use of catch crops. Agric Ecosyst Environ 255:1-11. https://doi.org/10.1016/j.agee. 2017.12.009

Quinteiro P, Rafael S, Vicente B, Marta-Almeida M, Rocha A, Arroja L, Dias AC (2019) Mapping green water scarcity under climate change: a case study of Portugal. Sci Total Environ 696:134024. https://doi.org/10.1016/j.scitotenv. 2019.134024

Rodrigues MA, Arrobas M (2020) Cover cropping for increasing fruit production and farming sustainability. In: Srivastava $\mathrm{AK}, \mathrm{Hu} \mathrm{C}$ (eds) Fruit crops: diagnosis and management of nutrient constraints. Elsevier, The Netherlands, pp 279-295

Rodrigues MA, Coutinho J, Martins F (2002) Efficacy and limitations of triticale as nitrogen catch crop in a Mediterranean environment. Eur J Agron 17:155-160

Rodrigues MA, Pavão F, Lopes JI, Gomes V, Arrobas M, Moutinho-Pereira J, Ruivo S, Cabanas JE, Correia CM (2011) Olive yields and tree nutritional status during a fouryear period without nitrogen and boron fertilization. Commun Soil Sci Plant Anal 42(7):803-814

Rodrigues MA, Santos H, Ruivo S, Arrobas M (2010) Slowrelease $\mathrm{N}$ fertilisers are not an alternative to urea for fertilisation of autumn-grown tall cabbage. Eur J Agron 32(2):137-143

Rodrigues MA, Torres LdD, Damo L, Raimundo S, Sartor L, Cassol LC, Arrobas M (2021) Nitrogen use efficiency and crop yield in four successive crops following application of biochar and zeolites. J Soil Sci Plant Nutr. https://doi.org/ 10.1007/s42729-021-00421-3

Sesták Z, Castky J, Jarvis PG (1971) Plant photosynthetic production: manual of methods. Dr. W. Junk Publishers, The Hague, The Netherlands

Trenkel ME (2010) Slow- and controlled-release and stabilized fertilizers. An option for enhancing nutrient use efficiency in agriculture. International Fertilizer Industry Association, Paris, France 
Vashisth T, Kadyampakeni D (2020) Diagnosis and management of nutrient constraints in citrus. In: Srivastava AK, Hu C (eds) Fruit crops: diagnosis and management of nutrient constraints. Elsevier, The Netherlands, pp 723-737

von Caemmerer S, Farquhar GD (1981) Some relationships between the biochemistry of photosynthesis and the gas exchange of leaves. Planta 153:376-387. https://doi.org/ 10.1007/BF00384257

Wei X, Chen J, Gao B, Wang Z (2020) Role of controlled and slow release fertilizers in fruit crop nutrition. In: Srivastava $\mathrm{AK}, \mathrm{Hu} \mathrm{C}$ (eds) Fruit crops: diagnosis and management of nutrient constraints. Elsevier, The Netherlands, pp 555-566

Wright SF, Upadhyaya A (1998) A survey of soils for aggregate stability and glomalin, a glycoprotein produced by hyphae of arbuscular mycorrhizal fungi. Plant Soil 198:97-107
Wu ZZ, Ying YQ, Zhang YB, Bi YF, Wang AK, Du XH (2018) Alleviation of drought stress in Phyllostachys edulis by $\mathrm{N}$ and P. Sci Rep 8:228. https://doi.org/10.1038/s41598-01718609-y

Yang Y, He C, Huang L, Ban Y, Tang M (2017) The effects of arbuscular mycorrhizal fungi on glomalin-related soil protein distribution, aggregate stability and their relationships with soil properties at different soil depths in leadzinc contaminated area. PLoS ONE 12(8):e0182264. https://doi.org/10.1371/journal.pone.0182264

Publisher's Note Springer Nature remains neutral with regard to jurisdictional claims in published maps and institutional affiliations. 